\title{
Application of task-based teaching method in English classroom teaching
}

\author{
Zhao Hui Min ${ }^{1, \text { a }}$ \\ ${ }^{1}$ Bohai university, Jinzhou, 121013 China \\ ahmzhao2008@163.com
}

\begin{abstract}
Keywords: English teaching; method research; teaching mode; exploration task teaching method; exploration task teaching method.
\end{abstract}

\begin{abstract}
Professional English is the product of social demand, which aims to improve students' ability to communicate in English, and professional English teaching has attracted more and more attention. Many linguists and educators have put forward a lot of theories and methods in English teaching, which have greatly promoted the professional English teaching and learning. The task-based teaching is the method worthy of implementation. Its main purpose is to let students use and learn, directly through classroom teaching, and ask students to use English in the real life, study and work in various situations, so as to cultivate students' comprehensive ability of using English. Task based teaching fully respects the students' subjectivity, and it is one of the best ways to effectively change the teaching situation which is mainly teacher-centered.
\end{abstract}

\section{Introduction}

Task based teaching method (approach task-based) is a teaching method based on the theory of "constructivism" (constructivism). This theory holds that the student's access to knowledge mainly does not depend on the teacher, but the learner in certain situations (i.e., social and cultural background), with the help of others (including teachers and learning partners) help, and use the necessary learning materials, through the way of obtaining meaning construction. Construction is not only the construction of new knowledge meaning, but also includes the transformation and reorganization of the original experience. The principle is: the students' learning activities and tasks or combination, in order to explore questions to guide and maintain the learning interest and motivation; create a real teaching environment, let the students with the real task to learn, in this process, students have the learning initiative, guide and encourage teachers actively that makes students learn content and grasp through the task by analogy [1]. The task-based teaching is based on real-life communicative needs determine the language learning task, students from around the task planning and through their own efforts to achieve the plan, to complete the task, and to evaluate their own learning in the process (Ellis, 1999). Specifically, it takes the student as the center, takes the duty as the driving force, the method and the goal, the student in the practice using the existing knowledge, the skill, obtains the new knowledge and enhances the skill [2].

\section{The feasibility of carrying out the task based teaching method in English Teaching}

\section{Task based approach.}

Specialized English or in a broad sense, it is the development of language learning to information communication, and it is a course of combination of language application and professional knowledge. It involves not only the knowledge of language and linguistic knowledge, education, also relates to a specific professional knowledge, and is the specific purpose according to the learner's specific needs and set up English Course (Hutchinson and Waters 1987). The purpose is to develop students' ability to use English in a certain working environment, business English, architectural English, financial English, medical English, computer English, legal English and so on. In 2000 promulgated the "College English Teaching Syllabus for English Majors" training objectives clear: "high school English professional training of the English language has a solid foundation and a broad 
range of cultural knowledge, and skilled use of English in foreign affairs, education, trade, culture, science and technology, military and other departments engaged in translation, teaching and management and research work of compound talents." Specialized English teaching takes the task of promoting the students to complete the transition from the basic stage to the application stage. It is not only to teach English, it is not simply to impart professional knowledge, but to practice based training, so that students learn in the field of English in the field of practical significance of the exchange [3].

\section{Development of professional English Teaching.}

Professional English teaching experience of register analysis, rhetorical or discourse analysis, scenario analysis, strategy analysis and learning skills and learning centered five stages of development (Hutchinson \& Waters 1987: 9 - 14). Register analysis research center at the sentence level, teaching emphasis on grammar. The teaching of rhetoric or discourse analysis is focused on the study of the discourse organization patterns outside the sentence level, the linguistic approach to these patterns and the characteristics of communication. The teaching of the target scenario analysis is a systematic exposition of the communicative approach, and it is believed that the purpose of professional English teaching is to enable learners to use the language freely in the target context. Skills and learning strategies in the analysis phase of the professional English teaching focus on language teaching, skills, especially reading skills teaching and research. At the center of learning, professional English teaching emphasizes the full mobilization of the enthusiasm of teachers and students, the choice of the way the language of the use and learning organically combined. In the first three stages, the surface structure of the language is discussed, and the process of using language is discussed in fourth stages. Only fifth stages combine the use of language and the study of language. Task based teaching method is a learning centered approach, that is, the use of language and language learning organically combined, more conducive to the initiative to promote students to explore the language[4].

\section{The application of task based teaching method.}

Professional English has a number of categories, the author in a few years of Construction English, computer English and other professional English teaching; try a variety of teaching methods, in which the task of teaching practice has achieved good results. Taking the teaching of "construction contract agreement" as an example, this paper introduces the practice of teaching activities by using task based teaching method. In order to make students to read and write English construction contract to allow students to carry out teaching activities in a task driven, to guide the students, from the outside to the inside layer depth, step by step to complete a series of tasks, and gradually get clear ideas, methods and knowledge context. Task design is the key of task teaching method. According to the contents of this section, the teacher through the status quo and analysis of students' needs, determine the goal is to enable students to read and write English skilled construction contract agreement, namely the teaching task of making a construction contract agreement, and the task from two aspects of the structure and style is divided into the following several specific and simple small task.

\section{Factors that affect the implementation of the task}

\section{The full extent of the information provided.}

For example, is familiar in daily life or more professional or obscure; fourth, discourse types of cohesive devices in information organization. In addition, the purpose of the listener also affects the difficulty of the implementation of the task. The purpose of the so-called "listener" refers to the way and degree of understanding and processing the text according to the task. Such as identification, positioning, focusing on understanding, detailed understanding, comprehensive understanding, reasoning, etc... If only to identify, judge the name, place name, the name of things, advertising in the adjective, the task is very difficult, such as the requirements of a comprehensive understanding, or need to reasoning information, the task is to increase the difficulty of the task. From the above we can 
know that in the design of the task, the factors that affect the difficulty of the task are varied. Teachers should be based on the specific circumstances of the students, various factors of task difficulty in comprehensive analysis of influence of different tasks, the task of selecting suitable collocation principle, at the same time use or provide necessary auxiliary means, will be adjusted to the appropriate level of task difficulty, so that the task is operational, the authenticity of the teaching to achieve the best results. Under the guidance of teachers, make students learn knowledge in training activities, interpersonal communication, thinking, decision-making and strain ability, make the students all-round development.

\section{Extended task factor.}

In the classroom teaching, through the inspection and evaluation tasks, most of the students have mastered the writing method of construction engineering contract agreement, that is to say, to complete the task assigned by the teacher, but this is not the final goal of learning. If at this time for students to inspire innovative thinking, so that students can actually simulate the whole process of signing the contract will be more helpful to cultivate students' innovative ability and practical ability. The students were divided into two groups, respectively, as the owner and the contractor, the first to confirm the specific objectives of the contract, and then study the specific terms of the contract, then make tentative agreement, finally signed the contract. Since the class time is limited, can be arranged for students to complete the class, so that students can also have enough time to access the relevant information, to discuss and cooperate with each other until the final completion of the task.

\section{Evaluation and promotion of task factors.}

After the completion of the task, the teachers and students themselves have to clear the task of completing the quality, that is, the task of the completion of the evaluation of students. Evaluation methods can be flexible, student self-assessment, peer assessment, in every kind of evaluation; the students can fully demonstrate their achievements, to learn from each other, learn from each other, improve the purpose. For example, you can start with individual students to report to the class to write their own construction contract agreement, by the other students to evaluate; can also be in the group for detection and evaluation of each other, elected representatives report to the group to complete the situation, let other students evaluation. No matter what kind of evaluation, teachers should be based on positive guidance, more praise, more encouragement, and timely to point out the existing problems [5].

\section{Research teaching model.}

Study of teaching refers to the teachers to set up multi-dimensional learning situation, ask questions or to provide clues, study guide students through their own learning, teamwork, way to accumulate knowledge, find a way to solve the problem, you get the conclusion, the cultivation of students' autonomous learning ability and innovation ability, language expression and communication a kind of teaching mode, practical ability and cooperation ability and quality. This mode breaks through the traditional classroom centered closed teaching mode, which has the characteristics of subjectivity, openness, practicality and so on, which can arouse students' learning initiative. The implementation and application of the training for the production, construction, management and service needs of the first line of "going down, stay useful" research teaching mode, high skill talents and strong practice ability and good occupation morality of higher occupation education plays a positive role, it is a new ideas for the reform of English Teaching mode in Higher Vocational education. The author believes that the implementation of research-based teaching model in Higher Vocational College English teaching will play a positive role in the realization of the goal of Higher Vocational English teaching. 


\section{Study on case teaching method}

\section{Method summary.}

Professional English teaching goal is to cultivate students' English communicative ability in the work environment, meet the need of social communication in real life, and the task teaching method is in line with professional English tools and practical characteristics, because the whole process of the cultivation of the decomposition ability of language application using task-based teaching method to each the task of teaching, the students with the real task to explore learning, continuous training in finish a task and expand students' survival ability and work ability. It can be seen that the task teaching method is especially suitable for the teaching of professional English courses, and it is easy to achieve the goal of professional English teaching.

\section{Situational teaching method.}

Situational teaching method (SLT) in 1920s, it is Palmer who has done a lot of research in foreign language teaching method is scientific, systematic, formed in succession based on the traditional direct method more perfect teaching system. The so-called situational teaching method, is the use of visual aids, real life, body language, English listening materials, multimedia and other situational, entertaining, so that students enjoy learning English in full in the visual environment, to improve the teaching effect of A. Practice has proved that the effective teaching situation creation, can stimulate the student to study the interest and the English expression ability, greatly improves the English classroom teaching efficiency. For a long time, the foreign language teaching in our country pays attention to the traditional teaching method, the teacher and the book as the center, and the students are in the passive position. Obviously, this kind of teaching mode is not conducive to the cultivation of students' interest; mobilize the enthusiasm of the students. In recent years, situational teaching has been paid more and more attention, and has been applied to the practice of foreign language teaching, and has received good results. Practice has proved that the effective teaching situation creation can stimulate the student to study the interest and the English expression ability, greatly improves the English classroom teaching efficiency. English teaching is a language teaching can not be separated from the emotional communication between people, and the exchange of the need for a certain scene. In English teaching, teachers should create an open, harmonious, active and interactive language activities atmosphere, to produce invasive effect, that is to let the students enjoy fusion in an English environment, naturally imperceptibly absorb and practice, enhance the sense of language, to improve oral English ability and the overall level of.

\section{Key issues that need to be addressed.}

In view of the situational teaching method in China has been started, but there are many problems in the process of implementation, such as the use of the development of education led to uneven teaching method is not balanced, the situational teaching method has attracted attention in the Midwest economy owes the developed yet; the education system is not perfect, resulting in the situational teaching method with the teaching goal of touch and so on. The purpose of this paper is to analyze the patterns and the use of situational teaching methods and the advantages and necessity, and put forward relevant suggestions to improve, so that this model can be more perfect, to achieve universal use.

\section{Construction and thinking.}

Since the beginning of 1990s, the world foreign language teaching has entered into the post education era, and the situational teaching method has been widely concerned as one of the most important achievements. In our country, this kind of teaching method although there is no independent teaching method as a system, but the mastery of language knowledge in the scene, so as to understand and express, communicative competence, which is a kind of teaching mode is widely used in foreign language teaching, and the scene in communicative linguistics appears more superiority. Reflect the current proposed the concept of the new curriculum. Richard in the research abroad, J.C., and 
Rodgers, a preliminary exploration, T.S. and other scholars on the theory and practice of situational teaching method in the later scholars' research, by Brimful in his book The Functional-Notional Approach from Theory to Practice: the scene teaching method has a deeper analysis of the most representative. In China, scholars Chang Linzhu in "proposition teaching and quality education in college foreign language teaching" China clearly introduce the important teaching method and advocate the use of educators, Liu Yong, Sun Shuxia etc. to explore and Practice on it, and achieved certain results.

\section{Summary}

In English teaching, task-based language teaching effect is very significant, it gives students the opportunity to express themselves and communicate the platform, to stimulate students' independent thinking, is conducive to maintain the enthusiasm of English learning, to develop good language acquisition. Under the guidance of teachers, the teaching activities are stepped forward, so that the learning process of language is automatic and independent. But it is a new way of language teaching, need to continue to explore, in the process of teaching practice; so as to accumulate the essence, make the task-based teaching model achieves almost perfect effect on English learning. The concept and characteristics of the situational teaching method, as well as its origin and development at home and abroad, and according to the situational teaching method in middle school English education and the advantages of our country's development situation, put forward the situational teaching method in the necessity that our country use, and introduces the situational teaching method in China's specific use. Secondly, this paper introduces the method of situational teaching in middle school English, analyzes the obstacles in the way of situational teaching in our country. Finally, through the analysis of the obstacles to give some improvement suggestions.

\section{Acknowledgements}

This work is supported by Social Science Foundation of Liaoning Province (No. L15DWW005) and Bohai University Teaching Reform Project (No.BDJG15QNB002).

\section{References}

[1] Wang Fang. Scaffolding Teaching in the teaching application in the elective 6 unit second reading class for example [J]. overseas English version teach high school English reading. 2013 (12).

[2] flat petrels. Clever take teaching support, enhance the discourse teaching effectiveness of [J]. primary school teaching research. 2013 (13).

[3] Li Danli. The construction of [J]. foreign language teaching and research in Teachers "scaffolding" in the two language classroom interaction discourse (04) (2012).

[4] Liu Xiaoying. The combination of Scaffolding Teaching Mode and English Teaching in senior high school [J]. Journal of Qiqihar Teachers College. 2012 (03).

[5] Han Chengfeng. The effect of improving the teaching of reading through the scaffolding instruction [J]. Journal of Foreign Language College of Shandong Normal University (Basic English Education). 2010 (06). 